\title{
THE FACTORS ASSOCIATED WITH BLEEDING IN PATIENTS USING WARFARIN
}

\author{
Varfarin Kullanan Hastalarda Kanama ile İlişkili Faktörler
}

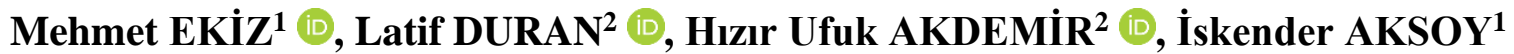 \\ ${ }^{1}$ Giresun Üniversitesi Tıp Fakültesi, Prof. Dr. A. Illhan Özdemir EAH, Acil Tıp A.D., GIRESUN, TÜRKIYE \\ ${ }^{2}$ Ondokuz Mayls Üniversitesi Tip Fakültesi, Acil Tip A.D., SAMSUN, TÜRKIYYE
}

\section{ABSTRACT}

ÖZET

Objective: The most serious side effect of warfarin, an oral anticoagulant widely prescribed by many different disciplines, is bleeding. In this study, the factors affecting the bleeding complications resulting from the use of warfarin were investigated.

Material and Methods: In this study, 111 patients using warfarin and admitted to the emergency department with bleeding complaints were evaluated. All patients were divided into two groups as Group I (international normalized ratio >3.5) and Group II (international normalized ratio $\leq 3.5$ ) according to the "international normalized ratio" value at the time of admission. The groups were compared in terms of demographic characteristics, admission complaint, indications for warfarin use, concomitant diseases, other drugs used, duration of warfarin use, international normalized ratio value, bleeding localization, treatment and interventions.

Results: Of the 115 patients, 85 were in Group I and 26 were in Group II. Fifty-six $(50.5 \%)$ of the patients were women. In our study, the most common reason for warfarin use was heart valve replacement $(46.8 \%)$. The most common complaint was bloody stool (41.5\%). Of the patients, 79 of had at least one concomitant disease. The most common comorbid disease of our patients was hypertension ( $\mathrm{n}=50,45 \%)$. Seventy-six patients were found to have major bleeding and major bleeding was higher in Group I.

Conclusion: It was determined that major bleeding and need for hospitalization were higher in patients with an international normalized ratio value $>3.5$, and the follow-up period in the emergency department was longer. Although the international normalized ratio value is an important factor for warfarin-induced bleeding, the international normalized ratio value is not the only cause of bleeding and additional factors may be responsible for bleeding.

Keywords: Warfarin, hemorrhage, international normalized ratio, emergency
Amaç: Pek çok farklı disiplin tarafından yaygın olarak reçete edilen ve oral bir antikoagülan olan varfarinin en ciddi yan etkisi kanamadır. Bu çalışmada, varfarin kullanımı sonucu ortaya çıkan kanama komplikasyonu üzerine etkili olan faktörler araştırılmıştır.

Gereç ve Yöntemler: Bu çalışmada, varfarin kullanan ve acil servise kanama şikâyeti ile başvuran 111 hasta incelendi. Tüm hastalar başvuru anındaki "international normalized ratio" değerine göre Grup I (international normalized ratio $>3.5$ ) ve Grup II (international normalized ratio $\leq 3.5$ ) olmak üzere iki gruba ayrıldı. Gruplar demografik özellikler, başvuru şikâyeti, varfarin kullanma endikasyonu, eşlik eden hastalıklar, kullanılan diğer ilaçlar, varfarin kullanma süresi, international normalized ratio değeri, kanama lokalizasyonu, tedavi ve girişimler bakımından karşılaştırıldı.

Bulgular: Yüz on bir hastanın 85 'i Grup I'de ve 26'sı da Grup II'de yer almaktaydı. Hastaların 56's1 (\%50.5) kadındı. Çalışmamızda, varfarin kullanımının en yaygın nedeni kalp kapak replasmanı idi (\%46.8). En sık başvuru şikâyeti kanlı dışkılama (\%41.5) idi. Çalışmamızda hastaların 79'unda eşlik eden en az bir hastalık vardı. Hastalarımızın en sık görülen komorbid hastalığı hipertansiyon $(\mathrm{n}=50, \% 45)$ idi. Yetmiş altı hastada majör kanama olduğu ve majör kanamanın Grup I'de daha yüksek olduğu tespit edildi.

Sonuç: Uluslararası normalize oran değeri $>3.5$ olan hastalarda major kanamanın ve hastaneye yatış ihtiyacının daha fazla olduğu, acil serviste takip süresinin daha uzun olduğu tespit edilmiştir. Uluslararası normalize oran değeri, warfarine bağlı kanama için önemli bir faktör olmasına rağmen, kanamadan sorumlu tek neden uluslararası normalize oran değeri değildir ve kanamadan ek faktörler sorumlu olabilir.

Anahtar Kelimeler: Varfarin, kanama, uluslararast standardize oran, acil 


\section{INTRODUCTION}

Warfarin is used for treatment and prevention of arterial and venous thromboembolic diseases for many years. The prevention of thrombotic events is extremely important due to possible serious complications. The rational management of anticoagulant therapy is very important for vital aspect and prevention of complications. Vitamin $\mathrm{K}$ is required to be fully operational by blocking the synthesis of factor II, VII, IX, X clotting factors and deactivating protein $\mathrm{C}$ and protein S, natural anticoagulant proteins. Warfarin inhibits vitamin $\mathrm{K}$ by inhibiting vitamin $\mathrm{K}$-reductase and vitamin $\mathrm{K}$-epoxide reductase which produces reduced form of vitamin $\mathrm{K}$ (1). Warfarin provides anticoagulation with this mechanism. The laboratory and clinical studies have contributed to the understanding of risks associated with complex pharmacokinetic and pharmacodynamic structures, interactions, usage and antithrombotic effects of vitamin $\mathrm{K}$ antagonists (2). Bleeding is the most common side effect of coumarin-derivative anticoagulants due to a narrow therapeutic ranges (1).

The purpose of this study is to describe demographic (age, sex, initial complaint, localization of bleeding, concomitant illness, additional medications) and predisposing factors in warfarin-induced bleeding.

\section{MATERIALS AND METHODS}

The hospital records of patients admitted to emergency department with bleeding compliant within four years were retrospectively analyzed after approval by the ethics committee (Ondokuz Mayıs University Medical Research Ethics Committee; date:30.11.2011, issue number: OMU-TAEK 2011/471).

The inclusion criteria were; to be older than 18 years, to use warfarin at the admission time, to admit for bleeding complaint, not to have any known hematologic or hemostasis diseases leading to bleeding. The exclusion criteria were; the presence of trauma and the presence of known liver disease.

According to literature, the 2.5-3.5 range of international normalized ratio (INR) in patients with heart valve prostheses, atrial fibrillation (AF) and 2.03.0 range of INR in the other indications such as stroke and coronary artery disease are recommended (3). The INR value of 3.5 was assessed for supratherapeutic INR limit according to literature data. Patients were divided in two groups as group I: INR>3.5 and group II: INR $\leq 3.5$ according to the value of INR at initial admission.

After patients were divided to two groups as under the age of $65(<65)$ and over the age of $65(\geq 65)$; recorded data about demographic characteristics (age, gender), presenting symptoms, reason for using warfarin, concomitant diseases, other medications, duration of warfarin use, measured INR values, complete blood count, bleeding localization, treatment (vitamin K1 and/or fresh frozen plasma [FFP]) and duration of stay in the emergency department were evaluated. Patients were divided to two groups as major and minor bleeding according to severity and localization of bleeding. Intraabdominal, gastrointestinal, retroperitoneal, intracranial bleeding, intraorbital hemorrhage (without conjunctival hemorrhage), intramuscular bleeding associated with compartment syndrome, bleeding requiring invasive procedures, and ongoing bleeding which causes a decrease $2 \mathrm{~g} / \mathrm{dl}$ of haemoglobin level or blood pressure at $<90 \mathrm{mmHg}$ of systolic blood pressure or anuria for major bleedings; types of bleeding other than given above (epistaxis, gingival and cutaneous-subcutaneous hemorrhage etc.) for minor bleedings were evaluated (4).The information about discharge, hospitalization, transfer and death after treatment at the emergency department were evaluated.

\section{Statistical analysis}

The program "SPSS (Statistical Package of Social Sciences for Windows) 15" was used for evaluation of 
the data. Non-parametric Mann-Whitney U test was used because of abnormal distribution of our study and the presence of two groups. The significance level of $\mathrm{p}<0.05$ was considered for all statistical analyses.

\section{RESULTS}

There were 93754 admissions to our emergency department during four years but only 111 admissions were related with bleeding due to warfarin use. Of the patients included to the study, $85(88.4 \%)$ patients with $>3.5$ of initial INR value (group I) and 26 patients with $\leq 3.5$ of initial INR value (group II) were detected at admission.

Fifty-six patients $(50.5 \%)$ were female and 55 (49.5\%) were male. There was no statistically significant difference between gender and severity of bleeding $(\mathrm{p}>0.05)$. The average age of the patients was $65.6 \pm 11.2$ years. In our study, there were 60 patients under the age of 65 ( $<65$ years) and 51 patients over the age of $65(\geq 65$ years). When patients were compared between two groups in terms of age groups, there was no statistically significant difference $(\mathrm{p}>0.05)$. The most common complaint was bloody stools (41.4\%). Of these patients, while 35 were in group I, $23.9 \%$ of them were in group II. While 79 patients were found to have at least one comorbid disease, in $28.9 \%$ patients there was not any comorbid disease. The most common comorbid disease of our patients was hypertension. There was no statistically significant difference between severity of bleeding and comorbid diseases $(\mathrm{p}>0.05)$. The patients of demographic characteristics distribution and comparisons are shown in Table 1.

Table 1: Demographic characteristics of the patients

\begin{tabular}{lcccc}
\hline & $\begin{array}{c}\text { Total Patients } \\
\mathrm{n}(\%)\end{array}$ & $\mathrm{n}(\%)$ & $\mathrm{Group} \mathrm{II}$ & $\mathbf{n}(\%)$ \\
\cline { 2 - 5 } Age & $51(46)$ & $36(42.4)$ & $15(57.7)$ & 0.091 \\
$\geq 65$ & $60(54)$ & $49(57.6)$ & $11(42.3)$ & 0.091 \\
$<65$ & & & \\
Complaint at admission & 46 & $35(41.1)$ & $11(42.3)$ & 0.553 \\
Bloody stools & 15 & $10(11.8)$ & $5(19.2)$ & 0.429 \\
Hematuria & 11 & $9(10.6)$ & $2(7.7)$ & 0.669 \\
Abdominal pain & 10 & $9(10.6)$ & $1(3.8)$ & 0.298 \\
Bloody vomiting & 7 & $4(4.7)$ & $3(11.5)$ & 0.213 \\
Altered mental status & 6 & $6(7)$ & - & 0.167 \\
Bloody sputum & 9 & $7(8.2)$ & $2(7.7)$ & 0.930 \\
Ecchymosis on the skin & 4 & $2(2.3)$ & $2(7.7)$ & 0.205 \\
Nose bleeding & 2 & $2(2.3)$ & & 0.435 \\
Shortness of breath & 1 & $1(1.2)$ & - & 0.583 \\
Gingival bleeding & & & & \\
Clinical results & 29 & $19(22.4)$ & $10(38.5)$ & 0.375 \\
Hospitalization & 80 & $64(75.3)$ & $16(61.5)$ & 0.145 \\
Discharge & 1 & $1(1.2)$ & - & 0.583 \\
Transfer & 1 & $1(1.2)$ & - & 0.583 \\
Death & & & & \\
\hline
\end{tabular}


There was additional drug use in 79 patients. There was at least one drug that can interact with warfarin in 40 patients. The most common drugs that can interact with warfarin were drugs containing acetylsalicylic acid $(\mathrm{n}=33,82.5 \%)$. There was no statistically significant difference between severity of bleeding and additional drug use $(\mathrm{p}>0.05)$.

The most common indication for warfarin use was the presence of cardiac valve prosthesis $(46.8 \%)$. While 37 patients were in group I, 15 patients were in group II. The indications for warfarin use according to groups of patients are given in Table 2.

While the lowest measured value of INR was 1.16 , the maximum INR value was 10.2. The average INR value was found as $4.73 \pm 1.95$. The average INR value in group I was $5.74 \pm 1.52$ while the average INR value of the patients in group II was $2.66 \pm 0.67$. There was no statistically significant difference between groups in terms of INR values $(\mathrm{p}<0.05)$.

The mean haemoglobin level was $9 \pm 2.96 \mathrm{~g} / \mathrm{dL}$, hematocrit was $26.6 \pm 8.58 \%$ and the platelet value was $239.000 \pm 91.000 / \mathrm{mm}^{3}$. The mean haemoglobin and hemotocrit levels were found to be lower in group I than the other group. While the mean haemoglobin value in major bleedings was $8.9 \pm 2.9 \mathrm{~g} / \mathrm{dL}$, the mean haemoglobin value in minor bleeding was 10.6 \pm 2.4 $\mathrm{g} / \mathrm{dL}$. There was no statistically significant difference between groups with major and minor bleeding based on haemoglobin level ( $p>0.05)$, but there was a statistically significant difference between platelet count and bleeding severity $(\mathrm{p}<0.05)$ (Table 3$)$.

Table 2: The indications of patients for warfarin use according to groups

\begin{tabular}{lccc}
\hline & Group I & Group II & p \\
& $\mathrm{n}(\%)$ & $\mathrm{n}(\%)$ & \\
\cline { 2 - 4 } Valve replacement & $37(43.5)$ & $15(57.7)$ & 0.209 \\
Atrial fibrillation & $19(22.3)$ & $7(26.9)$ & 0.544 \\
Stroke / TIA* & $10(11.8)$ & - & 0.068 \\
Coronary artery disease & $10(11.8)$ & - & 0.068 \\
PTE** & $2(2.4)$ & $4(15.4)$ & 0.010 \\
Deep vein thrombosis & $4(4.7)$ & - & 0.264 \\
Peripheral arterial disease & $3(3.5)$ & - & 0.336
\end{tabular}

*Transient ischemic attack **Pulmonary thromboembolism 
Table 3: The distribution of patients according to laboratory parameters

\begin{tabular}{lcccc}
\hline & Total & Major & Minor & p \\
Laboratory test & Mean $\pm \mathrm{SD}^{*}$ & Mean \pm SD & Mean \pm SD & \\
\hline INR** & $4.73 \pm 1.95$ & $4.75 \pm 1.9$ & $4.54 \pm 1.6$ & 0.769 \\
Haemoglobin (gr/dL) & $9 \pm 2.96$ & $8.9 \pm 2.9$ & $10.6 \pm 2.4$ & 0.071 \\
Hematocrit $(\%)$ & $26.6 \pm 8.58$ & $26 \pm 8.6$ & $31 \pm 6.8$ & 0.054 \\
Platelet $\left(/ \mathrm{mm}^{3}\right)$ & $239.000 \pm 91.000$ & $246.000 \pm 86.000$ & $173.000 \pm 113.000$ & 0.014 \\
\hline
\end{tabular}

*Standard deviation, **International normalized ratio We found presence of major bleeding in 76 patients and minor bleeding in $31.5 \%$ patients. Major bleeding was higher in patients of group I. There was no significant difference between groups based on severity of bleeding ( $>0.05)$. When the distribution of age $(<65$ and $\geq 65$ years) was compared for major and minor bleeding, there was no statistically significant difference between the distribution of age and severity of bleeding ( $p>0.05)$. The most common localization of bleeding was gastrointestinal bleeding $(n=55,49.5 \%)$. There was gastrointestinal bleeding in 43 patients $(50.5 \%)$ of group I and 12 patients $(46.1 \%)$ of group II. The distribution of bleeding localization according to groups and severity of bleeding are given in Table 4 .

The average duration of warfarin use was $61 \pm 78$ months in study population. In group I, average duration of warfarin use $62 \pm 74$ months, in group II was $57.3 \pm 90$ months. There was no statistically significant difference in groups according to the duration of warfarin use ( $>0.05)$. There was also no statistically significant difference between duration of warfarin use and severity of bleeding ( $\mathrm{p}>0.05)$.

In emergency department, the treatment of FFP replacement was found with in 109 patients and erythrocyte suspension transfusion in 73 patients. The average replacement was $4.97 \pm 3.29$ units of FFP and $5.62 \pm 2.98$ units of erythrocyte suspension in our study population. Vitamin $\mathrm{K}$ was given to 10 patients and all of them were in group I. There was a statistically significant difference between treatment (FFP and erythrocyte suspension ) and severity of bleeding $(\mathrm{p}<0.05)$. The time of observation (follow-up and treatment) in emergency service was $43.41 \pm 28.74$ hours. Patients of group I stayed in emergency service during for an average of $43.7 \pm 29.2$ hours while patients in group II stayed during an average of $42.3 \pm 27.7$ hours. Eighty-one patients stayed for more than 24 hours in emergency service. Of these 81 patients, 62 patients were in group I and the other $23.5 \%$ were in group II. There was no statistically significant difference between groups based on the duration of stay in emergency service ( $p>0.05)$. The average duration in the emergency service was found to be $46 \pm 28.8$ hours in patients with major bleeding and $18.8 \pm 8.9$ hours in patients with minor bleeding.

When the clinical results after treatment were evaluated, it was detected that $72.1 \%$ patients were discharged from emergency department, 29 patients were hospitalized, one patient died due to intracranial hemorrhage and one patient was transferred to another hospital. 
Table 4: The distribution of bleeding localization according to groups and severity of bleeding

\begin{tabular}{|c|c|c|c|c|}
\hline & $\begin{array}{c}\text { Group I } \\
\mathrm{n}(\%)\end{array}$ & $\begin{array}{c}\text { Group II } \\
\mathrm{n}(\%)\end{array}$ & $\begin{array}{c}\text { Major } \\
\text { n }(\%)\end{array}$ & $\begin{array}{l}\text { Minor } \\
\text { n }(\%)\end{array}$ \\
\hline GIS* & $43(50.6)$ & $12(46.2)$ & $55(72.3)^{\text {*** }}$ & - \\
\hline Intraabdominal & $12(14.1)$ & $2(7.7)$ & $14(18.4)$ & - \\
\hline GUS** & $8(9.4)$ & $5(19.2)$ & - & $13(37.1)$ \\
\hline Respiratory tract & $9(10.6)$ & - & - & $9(25.7)$ \\
\hline Intramuscular & $6(7.1)$ & $2(7.7)$ & - & $8(22.8)^{* * *}$ \\
\hline Intracranial & $4(4.7)$ & $3(11.5)$ & $7(9.2)$ & - \\
\hline Nasal & $3(3.5)$ & $2(7.7)$ & - & $5(14.3)^{* * *}$ \\
\hline
\end{tabular}

*GIS: Gastrointestinal system, ${ }^{* * G U S: ~ G e n i t o u r i n a r y ~ s y s t e m, ~}{ }^{* *} \mathrm{p}<0.001$

\section{DISCUSSION}

The most important and feared complication of anticoagulant therapy is bleeding which can cause serious morbidity and mortality. So the rational management of anticoagulant therapy is very important for the prevention of complications and vital aspect. The incidence of bleeding due to warfarin overdose is not fully expressed in the literature. However the incidence of bleeding due to warfarin was found to be 15.2 per 100 patient-years in a study (5). There is a similar uncertain condition on the incidence of major and minor bleeding. This condition is related with the absence of specific criteria for determining the severity of bleeding. The incidence of major bleeding was reported to be $7 \%$ in a study which includes the follow-up results of 579 patients whose warfarin therapy was started newly (6). Warfarin-induced bleeding complication can occur at any age, but it was reported to occur more in patients with age more than 50. According to their study involving 562 patients receiving warfarin therapy, Landefeld et al. reported that the patients over 65 years had 3.2 times greater risk of major bleeding than the other groups (7). Wallvik et al. have reported the risk to be increased 2.9-fold in patients with 60-69 years, 4.8 fold in 70-79 years and 6.6-fold in 80 and older years in their study which evaluated 195 major bleedings occuring in 2701 patients for 5 years in Northern Sweden (8). In our study, there was no statistically significant relevance between bleeding complication and age groups. Fanikos et al reported that the average age of patients with bleeding was 59.7 years in their study (9). We found the average age of patients to be $65.6 \pm 11.2$ years in our study population. The increased risk of bleeding with advancing age may be secondary to physiological changes in older age, additional diseases and multidrug use. It has been reported that $47.4 \%$ of all patients were male in a study about patients with supratherapeutic INR value and $46 \%$ of patients were female in another study $(1,10)$. In our study population, $50.5 \%$ were female. No relevance between gender and bleeding was detected.

The indications for warfarin were often cardiac causes (prosthetic heart valves, atrial fibrillation). It is reported that $\mathrm{AF}$ is the most common indication for warfarin use in other studies $(9,10)$.

Warfarin-induced bleeding may present in different ways. The most common complaint at admission was reported to be gastrointestinal bleeding (hematemesis, melena) in a prospective study which includes patients older than 65 years using warfarin (11). Similar to literature, the most common complaint was gastrointestinal hemorrhage in our study population. 
In several studies, hypertension, history of gastrointestinal bleeding and brain vascular disease are reported to be higher risks for bleeding (4). Similarly, the history of gastrointestinal bleeding was reported to increase the risk of major bleeding 2.9-fold in another study (7). In our study population, the most common additional diseases were hypertension, heart failure, coronary heart disease and diabetes. We think that higher risk of bleeding in patients with additional diseases may be related to multidrug use, drug interactions and gastrointestinal side effects.

Drugs increasing the efficiency of warfarin or drug interaction are important factors increasing bleeding risk. However, certain food also affect intestinal absorption, binding ratio to albumin and hepatic metabolism of warfarin in the liver (12). In a study, drug interactions were reported to play a role in half of warfarin-induced bleeding (13). There was at least one drug use which may have increased warfarin effects such as antiaggregant medication (acetylsalicylic acid) in approximately one third of patients and antidepressant medication (selective serotonin reuptake inhibitors and tricyclic antidepressants) in $5.4 \%$ of patients in our study population. Acetylsalicylic acid was found as a commonly used drug in patients, when compared to other drugs interacting with warfarin. According to a study on drug interactions, it was reported that the couse of warfarin and cephalosporin antibiotics could increase the risk of bleeding compared with warfarin use alone but there was no similar relationship in warfarin use together with nonsteroidal inhibitor drugs / cyclooxygenase-2 inhibitors, amiodarone, fenofibrate (14). We found that as almost all of the bleedings due to drug interaction in our study were major bleedings, only with minor bleedings presenting as minority.

Warfarin is a drug with a complex pharmacokinetic structure and frequently and closely follow-up is required for the recommended INR value (2). It is reported that INR value may show variability by $60 \%$ between individuals, by $11 \%$ in the same individual at different times and this is related with age, gender, other drugs used and genetic structure of the warfarin user (15). It was reported that there was a direct relationship between the increase in INR level and the risk of bleeding in patients taking warfarin and this risk was found to be increased when the INR value was over 5 in the studies investigating this subject $(4,16)$. We found that bleeding due to warfarin was more frequent in the patients with supratherapeutic INR values in our study. Although the INR value was within the recommended values, bleeding has occurred in approximately onequarter of patients in our study population and so we think that bleeding is not related only to INR level. Comorbid disease and additional drug use may be responsible for bleeding. There were some studies indicating a weak relationship between the severity of bleeding and INR levels in literature (17). A study shows that even if the prothrombin time is in the recommended therapeutic range, major bleedings often occur and there is no clear relationship between major bleeding or the severity of bleeding and anticoagulant effect (18). The rate of major bleeding found to be $1-12 \%$ in warfarin users (7). Major bleeding was detected in a large number of patients in our study population.

Bleeding due to warfarin therapy may occur at different times after initiation of treatment. It was reported that bleeding especially in the first one-month period may be associated with the personal characteristics of patient rather than INR level (19). The ratio of major bleeding during this period was reported to be $1.3 \%$ (16). A large portion of bleeding have been shown to have occurred within the first 90 day after anticoagulation (9). Warfarin-induced bleeding was detected in majority of patients with history of long-term warfarin treatment longer than twelve months in our study population.

Warfarin-induced bleeding can occur in many different tissues and organs including brain, gastrointestinal tract and/or genitourinary tract. There exists different information about localization of bleeding due to warfarin in the literature. Warfarin-induced bleeding is 
reported to occur most frequently in gastrointestinal tract $(11,17)$. On the contrary, the most common bleeding due to warfarin was found to be intracranial in another study (18). The most common bleeding localization was gastrointestinal tract in our patients. Half of patients showed signs associated with gastrointestinal bleeding.

Vitamin $\mathrm{K}$ is recommended as an effective treatment in patients with high INR levels due to warfarin-induced coagulopathy. The administration of low-dose oral vitamin $\mathrm{K}$ in patients without bleeding is expressed to decrease the therapeutic level of INR fast and safely (19). Garcia et al. reported applying vitamin $\mathrm{K}$ in only $8.7 \%$ of patients with warfarin-induced coagulopathy and follow-up in half of patients (16). Intravenous vitamin $\mathrm{K}$ and FFP are recommended in patients with major bleeding due to warfarin use (19).

It was detected that FFP was preferred rather than vitamin $\mathrm{K}$ in our study which evaluated the approaches for treatment of increased INR levels. Dental et al. have recommended to administer intravenous vitamin $\mathrm{K}$ and coagulation factors to patients with major or lifethreatening bleeding, but have not reported any exact definitive statement about the most appropriative dosage and type of coagulation factor (19). Makris et al. reported that clotting factor concentrates were more effective in patients followed up in intensive care unit due to warfarin-induced coagulopathy according to their study which compared the effectiveness of FFP and clotting factors (4). We detected that FFP was administered to a large portion of patients and vitamin $\mathrm{K}$ was administered in a minority of our study population.

It was reported that a majority of patients with warfarin overdose stayed less than twenty-four hours in the emergency department and approximately one fifth of patients were hospitalized to related clinics (20). The elapsed time of our patients in emergency service was $43.41 \pm 28.74$ hours. We detected that while approximately one third of the patients in our study population stayed in emergency department less than twenty-four hours, the majority of patients were followed up and treated in emergency department. The rate of hospitalization in our study was $26.1 \%$ similar to literature.

It was determined that major bleeding with an INR value over 3.5 and the need for hospitalization were higher, and the follow-up period in emergency ward was longer in our study. The platelet count was statistically significantly higher in the group with major bleeding.

There are a few limitations of the study worth mentioning. Our study is retrospective and has a study duration of 4 years period; so these data most certainly should be confirmed in a larger, better randomized trial. According to our national data and results of our study; the early diagnosis and successful treatment of warfarininduced bleedings in the emergency department can be considered as a statement demonstrating the importance of emergency departments. Further prospective studies are needed to define for clinical characteristics and the severity of bleeding in the patients taking warfarin in our country.

Conflict of Interest: The authors declare that they have no conflict of interest.

Support and Acknowledgements: There is no funding source.

Researchers' Contribution Rate Statement: The authors declare that they have contributed equally to the article. Main idea-planning: HG, YG; analysis-interpretation: HG, YG; data provision: $\mathrm{HG}, \mathrm{YG}$; spelling: $\mathrm{HG}, \mathrm{YG}$; review and correction: $\mathrm{HG}, \mathrm{YG}$; affirmation: $\mathrm{HG}, \mathrm{YG}$.

Ethical Committee Approval: Ondokuz Mayıs University Medical Research Ethics Committee, date:30.11.2011, issue number: OMU-TAEK 2011/471.

\section{REFERENCES}


1. Visser LE, Bleumink GS, Trienekens PH, Vulto AG, Hofman A, Stricker BHC. The risk of over anticoagulation in patients with heart failure on coumarin anticoagulants. $\mathrm{Br} \quad \mathrm{J}$ Haematol. 2004;127(1):85-9.

2. Ansell J, Hirsh J, Hylek E, Jacobson A, Crowther M, Palareti G. Pharmacology and management of the vitamin K antagonists: American College of Chest Physicians evidence-based clinical practice guidelines. Chest. 2008;133(6):160S-98S.

3. Hirsh J, Guyatt G, Albers GW, Harrington R, Schünemann HJ. Antithrombotic and thrombolytic therapy: American College of Chest Physicians evidence-based clinical practice guidelines. Chest. 2008;133(6):110S-2S.

4. Makris M, Watson $H$. The management of coumarin-induced over-anticoagulation: Annotation. Br J Haematol. 2001;114(2):271-80.

5. Hollowell J, Ruigómez A, Johansson S, Wallander M-A, García-Rodríguez LA. The incidence of bleeding complications associated with warfarin treatment in general practice in the United Kingdom. Br J Gen Pract. 2003;53(489):312-4.

6. McMahan DA, Smith DM, Carey MA, Zhou XH. Risk of major hemorrhage for outpatients treated with warfarin. J Gen Intern Med. 1998;13(5):311-6.

7. Landefeld CS, Goldman OL. Major bleeding in outpatients treated with warfarin: incidence and prediction by factors known at the start of outpatient therapy. Am J Med. 1989;87(2):144-52.

8. Wallvik J, Själander A, Johansson L, Bjuhr Ö, Jansson J-H. Bleeding complications during warfarin treatment in primary healthcare centers compared with anticoagulation clinics. Scand J Prim Health Care. 2007;25(2):123-8.

9. Fanikos J, Grasso-Correnti N, Shah R, Kucher N, Goldhaber SZ. Major bleeding complications in a specialized anticoagulation service. Am J Cardiol. 2005;96(4):595-8.
10. Koo S, Kucher N, Nguyen PL, Fanikos J, Marks PW, Goldhaber SZ. The effect of excessive anticoagulation on mortality and morbidity in hospitalized patients with anticoagulant-related major hemorrhage. Arch Intern Med. 2004;164(14):1557-60.

11. Beyth RJ, Quinn L, Landefeld CS. A multicomponent intervention to prevent major bleeding complications in older patients receiving warfarin: a randomized, controlled trial. Ann Intern Med. 2000;133(9):687-95.

12. Shireman TI, Mahnken JD, Howard PA, Kresowik TF, Hou Q, Ellerbeck EF. Development of a contemporary bleeding risk model for elderly warfarin recipients. Chest. 2006;130(5):1390-6.

13. Quirke W, Cahill MR, Perera K, Sargent J, Conway J. Warfarin prevalence, indications for use and haemorrhagic events. Ir Med J. 2007;100(3):402-4.

14. Zhang K, Young C, Berger J. Administrative claims analysis of the relationship between warfarin use and risk of hemorrhage including drug-drug and drugdisease interactions. J Manag Care Pharm. 2006;12(8):640-8.

15. van Geest-Daalderop J, Pequeriaux N, Van den Besselaar A. Variability of INR in patients on stable long-term treatment with phenprocoumon and acenocoumarol and implications for analytical quality requirements. Thromb Haemost. 2009;102(3):588-92.

16. Garcia DA, Regan S, Crowther M, Hylek EM. The risk of hemorrhage among patients with warfarinassociated coagulopathy. J Am Coll Cardiol. 2006;47(4):804-8.

17. Denizbasi A, Unluer EE, Guneysel O, Eroglu S, Kosargelir M. Complications of warfarin therapy and the correlation of the outcomes with INR levels. J Emerg Med. 2006;2(30):241-2.

18. Levine MN, Raskob G, Beyth RJ, Kearon C, Schulman S. Hemorrhagic complications of 
anticoagulant treatment: the Seventh ACCP Conference on antithrombotic and thrombolytic therapy. Chest. 2004;126(3):287S-310S.

19. Dentali F, Crowther MA. Management of excessive anticoagulant effect due to vitamin $\mathrm{K}$ antagonists. ASH Education Program Book. 2008;2008(1):26670.

20. Ridker PM, Goldhaber SZ, Danielson E, Rosenberg Y, Eby CS, Deitcher SR et al. Long-term, lowintensity warfarin therapy for the prevention of recurrent venous thromboembolism. N Engl J Med. 2003;348(15):1425-34. 